\title{
Teaching Quality and Students Satisfaction: The Intermediatory Role of Relationship between Lecturers and Students of the Higher Learning Institutes
}

\section{Suarman}

\author{
Faculty of Education, University of Riau, Pekanbaru, Indonesia
}

\section{Doi:10.5901/mjss.2015.v6n2p626}

\section{Abstract}

This study was aimed to identify the intermediatory impact of relationship between lecturers and students towards students' satisfaction and lecturers' teaching quality. The study also examined the differences of perceptions on lecturers' teaching quality and students' satisfaction based on gender. This study used a cross-sectional model in determining the relationship between gender and students' satisfaction and their perception on the quality of the lecturers. The samples were university students consisted of 177 males and 273 females. 5-point scale questionnaires were used to measure students' satisfaction and their lecturers' teaching quality. The validity and reliability of the instrument had shown high values and was fit to be used in the actual study. The Manova test of inferential analysis was conducted to determine the differences of every aspect studied based on gender. Analysis of structural equation modeling ( SEM ) was conducted to identify the impact of relationship between lecturers and students as an intermediatory influence on teaching quality and students satisfaction. The results showed that the relationship between lecturers and students determines the lecturers' teaching quality and students' satisfaction. The findings confirm the role theory of relationship between lecturers and students and the impact of teaching quality in enhancing students' satisfaction as found in various studies conducted abroad, particularly on the constructs being studied. The findings of this study would provide recommendations for trainings or courses to be conducted for the purpose of improving the teaching quality of university lecturers, and helping lecturers to establish better relationship with their students.

Keywords: student satisfaction, teaching quality, gender, lecturer, relationship between lecturers and students.

\section{Introduction}

Tertiary education should inculcate a comprehensive and continous culture of quality services. Hence, one of the crucial values that should be integrated in the culture of quality is enhancing quality in the teaching and learning process. A study by Nor Hidayu Shahadan (2006) found that a lecturer's teaching quality would be different based on his/her professional qualification. It was found that lecturers who did not have professional education background were lacking in their method of teaching and did not really emphasise on their teaching objectives when conducting their teaching and learning session. This proven that it is important for university's lecturers to continously attending trainings or courses for the purpose of providing effective teaching and this aspect had encouraged the reseachers to conduct this study. The content of each lesson should be effectively delivered through various teaching methods. Impressive and creative approaches will ensure effective and smooth lectures, in addition to fun and meaningful lesson (Abdul Ghafar, 2003). Teaching methods are major elements to determine an impressive and fun conduct of teaching and learning process. During the lesson, the content should be delivered through effective and appropriate methods which not only fun but it must be easy for students to comprehend the content. The lesson is best delivered through clear voice projection as well as correct, clear, precise, and fluent language. The writing should be neat and appropriate so as to be clearly seen and read by all students. Lecturers should also be able to manage the activities and the time frame for their lesson needs to be well planned, which means the content should be delivered in a smart manner and appropriate pace.

Higher learning institutes should have effective leadership, knowlegable and professional educators, impressive learning and teaching facilities, quality students and relevant curriculum. These will gear and shape the institutions to be globally competetive. According to Umaedi (1999), the major role of a learning institution is producing quality human capitals for the nation. Quality education can be defined as the ability of the education system to provide the needs and expectations of the users/clients through continuous process of improvement. Success would be measured through the ability of the national higher education system in producing graduates who have impressive quality, as desired by the national educational principles and also marketable as needed by the job industries, innovative particularly on entreprenuership and the ability of the graduates to contribute for the community. Thus, efffective leadership plays a major role for a higher learning institute to ensure smooth execution and achievement of the strategic objectives as aimed 
by the institution. Therefore, highly educated and great lecturers are very important in providing effective teaching which later produce quality students.

\section{Literature Review}

One of the major responsibilities of the staff and lecturers is providing effective service and teaching. The efforts to improve the quality of teaching and learning are the priority of every higher learning institution and it is also one of the Government's important agendas, which is improving the quality of teaching and learning particularly at the tertiary level of education. Higher learning institutes have to adopt a sustainable culture of providing quality teaching and better learning. Quality teaching and better learning would always refer to appropriate teaching process, fulfilling teaching needs, and having the ability to anticipate clients and stakeholders' expectations in teaching and learning, the appearance of conducive physical facilities, friendly staff, and great administration services. Marsh and Hocevar (1990) defined teaching and learning quality as teaching effectiveness delivered by the academic staff, good and quality interaction between lecturers and students, which involves on how the lecturers entertain their students in the classroom, how they transfer information from the institution board to the students, or how they facilitate and motivate the students in the learning process. In this article, the quality of teaching and learning is referred to students' opinion based on their experience as students or clients of the program of study on the domains of their lecturers' teaching and learning quality.

The courses offered are parts of the higher education curriculum which aimed to attain certain objectives for the students. The university courses are the key components of higher education. According to Knight (2002) courses offered by the higher learning institutes were planned to provide maximum opportunities relating to experience, development and in-depth learning. In addition, according to Hamidah et. al (2004) the subjects for courses offered by colleges were designed not to burden the students but were formulated to meet the current needs of the job market. Motivation generates greater effort in providing better teaching and learning. In general it can be concluded that the lecturer's state of motivation is an internal state in influencing his/her teaching and learning process. Activities which are performed with higher motivation will have greater impact on the efforts made by a lecturer in his/her teaching and learning. Without motivation the learning process would be meaningless and ineffective.

Designing instructional methods will no doubt experience barriers and constraints particularly on the process of determining teaching objectives, teaching methods and in the decision of instructional media to be used as teaching aids. Other that designing lectures, lecturers would also need to determine instruments for performance assessment to measure students learning performance in achieving their learning objectives. This notion was once discussed by Groundwater et al. (2003) who stated that it is important for curriculum framework to have details information and description of knowledge, skills, process and outcomes for every learning stage. Quantity and quality of students interaction should be the educator's main focus. Apart from that, syllabus documents and curriculum frameworks should be written in inclusive with specific knowledge, skills, processes and outcomes of each level of study. Teaching quantity and quality of students during interaction in teaching and learning should be the major concerns of educators. Quantity refers to the frequency of students' interaction to discuss their learning subject; whereas quality refers to the learning aspects discussed by students. Interaction among students is considered as social relationships in the classroom. According to Mohammad Ashori (2007) interaction is a natural social relationship between individuals, in which individuals mutually influence each other simultaneously.

Relationship between students and lecturers is a key factor to determine the quality of classroom teaching and learning process. A good quality of relationship can better assist lecturers in implementing empathatic teaching and students can also receive the lessons well and vice versa if the relationship quality is bad, as the lecturer will not be able to perform well and students would psychologically reject the lecturer presence in the classroom. Good and effective interaction would be established when the teacher manages to create a two-way interaction between teachers and students through effective questioning techniques from the lecturer to the students as well as through questions asked by students to the lecturer (Kamarul Azmi, 2010).

Thus, establishing good relationship between lecturer and students is very important in teaching and learning for the students and lecturers to have a close emotional relationship, which later establish a two-way communication between students and lecturers. Lecturers should be effective and competent in performing his/her job demands. Lecturers should be competent and naturally master is/her learning contents, pedagogical knowledge, teaching medium, teaching methods and others. Each student has his/her own expectation, which normally expecting the lecturers to be good and efficient in teaching. Roediger, Thorsten and Isabelle (2007) had conducted a study on a number of students in Europe. The study found that students wanted their lecturers to be knowledgeable, enthusiastic, approachable and friendly. According to Hill et al. (2003) the quality of the lecturers is the most important factor in providing high quality of 
education.

According to Guolla (1999) satisfaction is an evaluation which takes place at the end of the process of consumer psychology after the use of a product or service. Students' satisfaction on their learning program is considered as a cumulative satisfaction of the entire program of their study. Students are clients who interests and satisfaction need to be prioritized as a dependent variable. According to Guolla (1999), students are clients and their satisfaction on certain educational products or services, resulted through interaction between lecturers and students during their teaching and learning process. Each teaching and learning activity has its own setbacks or constraints. Hence, students who can resolve obstacles and constraints have higher satisfaction than those who can not and relatively have lower satisfaction. Successfull students are those who know their own ability and capable in developing themselves through learning.

This study was conducted to get students' persceptions on various domains of teaching and learning quality. The impacts of the domains were then studied on students' satisfaction by applying customer satisfaction theory and educational psychology research on the samples who were students of a higher learning institution. This study was approached by incorporating customer satisfaction research into higher learning institution. This study is similar with many current studies which trying to relate various quality factors to measure customers' satisfaction, (Dutka, 1994). However, this research is still based on the existing research on educational psychologists to identify and measure the quality of teaching and learning.

\section{Methodology}

Respondents of this study were students of Riau University. Riau University was chosen to be studied due to its position as the top premier university in the Riau Province and it offers various fields of studies. The samples were selected through stratified random sampling based on gender. There were 177 male students and 273 female students. The total of respondents was 450 students. Items of the Questionnaire were to measure teaching quality from various aspects of courses (4 items), motivation (6 items), planning (5 items) lecturers-students relationship (8 items) and competency of the lecturers (4 items). Another six (6) items were to measure students' satisfaction. A pilot study was conducted on 200 students showed a high value of reliability and validity of the research instrument. The values for the items are; courses (0.78), motivation (0.83), instructional design (0.74), lecturer-students relationship (0.82), lecturers' competency (0.82) and students satisfaction (0.92). The first research objective was to investigate the difference of teaching quality and students' satisfaction based on gender. The second objective was to determine the function of teaching quality as intermediatory factor for gender and satisfaction. This study used the index matching measure which is commonly used as a benchmark to confirm the goodness or fitness of a model, including the root mean -square error of approximation ( RMSEA ), comparative fit index ( CFI ) and the normed chi-square ( X2/df ) (Hair et al. , 2006) .

\section{Findings}

\subsection{Differences on Lecturers' Teaching Quality and Students' Satisfaction Based on Gender}

The MANOVA analysis was carried out to identify differences in the teaching quality and students satisfaction based on gender. Results of the MANOVA analysis are shown in Table 1 below:

Table 1. Differences on lecturers' teaching quality and students satisfaction based on gender

\begin{tabular}{clcccc}
\hline Variables & $\mathrm{L}(\mathrm{n}=117)$ mean $(\mathrm{sd})$ & $\mathrm{P}(\mathrm{n}=273)$ mean $(\mathrm{sd})$ & Cohen's $\mathrm{C}$ & Sig. \\
\hline \multirow{2}{*}{ 1. } & Courses & 2.04 & 2.19 & 0.017 & 0.006 \\
& & $(0.51)$ & $(0.56)$ & & \\
2. & Lecturer's motivation & 2.72 & 2.84 & 0.015 & 0.010 \\
& & $(0.48)$ & $(0.48)$ & & \\
3. & Instructional design & 2.78 & 2.68 & 0.008 & 0.061 \\
& & $(0.56)$ & $(0.53)$ & & \\
4. & Lecturer-students relationship & 2.85 & 2.87 & 0.001 & 0.526 \\
5. & Lecturer's competency & $(0.46)$ & $(0.35)$ & & \\
& & 2.66 & 2.64 & 0.001 & 0.633 \\
6. & Students satisfaction & $(0.54)$ & $(0.53)$ & & \\
& & 3.75 & 3.93 & 0.019 & 0.003 \\
\hline
\end{tabular}


Based on the results above, it shows that male students had higher scores than female students on teaching quality. The significant difference was on two variables which were the courses and lecturers' motivation. The relationship between lecturers with male and female students did not indicate any significant difference. However, female students experienced higher satisfaction than male students. The significant different of means between the male and female students were then analysed by conducting the Cohen's $d$ analysis to determine the effect size. In overall the Cohen's $d$ values was at a low level (Kelley \& Preacher, 2012). The Cohen's d values for each variable are as follows: courses (0.017), lecturers' motivation (0.015), instructional design (0.008), lecturer-students relationship (0.001), lecturers' competency (0.001) and students' satisfaction (0.019). This shows that the difference was not significant.

\subsection{The Impact of Teaching Quality as intermediatory factor for Gender and students satisfaction}

The SEM was conducted to determine lecturer's teaching quality as the intermediatory influence for the relationship between gender and students satisfaction. Results of the SEM path analysis model showed Chi Square / df $=20.792$, Root Mean Square Error Approximation (RMSEA) $=0.02$, Goodness of Fit Index $(\mathrm{GFI})=1.00$ and Comparative Fit Index $(\mathrm{CFI})$ $=1.00$. All of the measures showed that the data used in this study proved to have reasonable accommodation for the proposed model (Byrne, 2010).

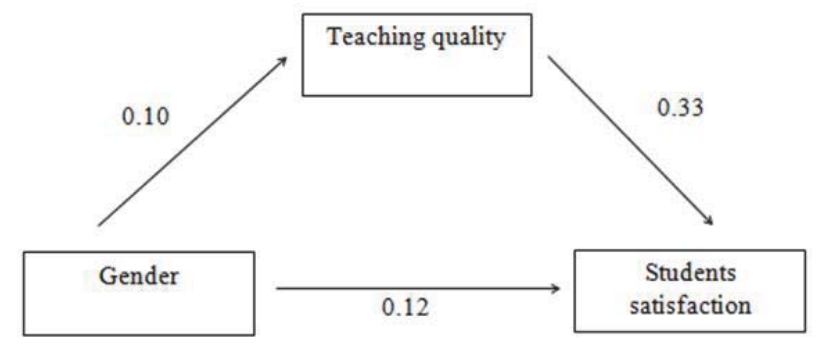

Figure 1. The intermediatory impact on relationship between gender and students satisfaction

Figure 1 above shows the intermediatory impact of teaching quality between gender and students satisfaction. There were three requirements to conduct an intermediatory analysis as proposed by Baron \& Kenny (1986). Firstly, the independent variable (i.e, gender) significantly predicted the dependent variable (i.e, student satisfaction). The overall effect of gender on students satisfaction was significant $(\beta=0.12, p<0.05)$. Female students showed higher satisfaction. Secondly, the independent variable ( i.e. gender ) significantly predicted the dependent variable (i.e. quality of the lecturers). The overall effect of gender on the quality of the lecturers was significant $(\beta=0.010, p<0.05)$. However, male students showed higher score on teaching quality when compared to female students. Thirdly, in overall, intermediatory variable (i.e, the lecturer's teaching quality) could significantly predict the dependent variable (i.e. student satisfaction $)(\beta=0: 33, p<0.05)$ after gender variable was controlled. Sobel test results to examine the effects of mediator showed significant results, $z=2: 78(p<0.05)$. Sobel test results confirmed that involvement was an intermediatory factor between gender and students satisfaction. This finding reconfirmed the intermediatory theory of the impact of gender on students satisfaction. The immediate effect of gender on students satisfaction was significant $(\mathrm{Ed}=$ $0.110, p<0.05$ ). Indirectly, there was an influence of gender on students satisfaction through teaching quality as mediator for the variables but the effect was not large, yet significant $(\mathrm{Ei}=0.072, \mathrm{p}<0.05)$.

\subsection{The impact of lecturer-students relationship as a medium for teaching quality and job satisfaction}

SEM was conducted to test the intermediatory impact of relationship between lecturers and students on lecturer's teaching quality and students' satisfaction. Results of the SEM path analysis model showed Chi Square / df $=12.104$, Root Mean Square Error Approximation (RMSEA) $=0.02$, Goodness of Fit Index $(\mathrm{GFI})=0.94$ and Comparative Fit Index $(\mathrm{CFI})=0.91$. All of the measures showed that the data used in this study was fit and had reasonable accommodation for the proposed model (Byrne, 2010) 


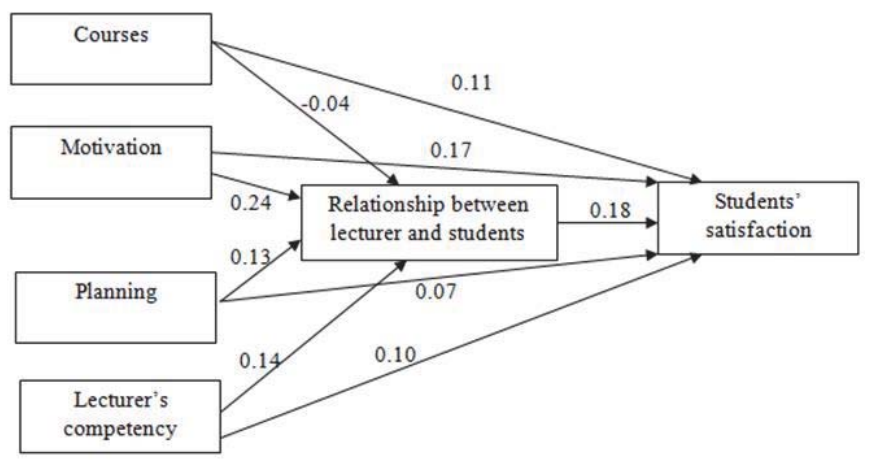

Figure 2. The intermediatory impact of relationship between lecturer and students on teaching quality and students' satisfaction

Figure 2 showed the intermediatory impact of relationship between lecturer and students on teaching quality and students' satisfaction. Firstly, the independent variables (i.e. courses, motivation, planning and lecturer's competency) significantly predicted the dependent variable (i.e. students' satisfaction). The overall impact of courses, motivation, planning and lecturer's competency on students' satisfaction was significant $(\beta=0.11, \beta=0.17, \beta=0.07, \beta=0.10$, $p<0.05)$. Secondly, the independent variables (i.e. courses, motivation, planning and lecturer's competency) significantly predicted the dependent variable (Lecturer-students relationship at the university). The overall impact of motivation, planning and lecturer's competency on students' satisfaction was significant $(\beta=0.17, \beta=0.07, \beta=0.10, p<0.05)$. However, courses did not have significant contribution on the relationship between lecturer and students. Thirdly, in overall, the intermediatory variable (i.e. lecturer-students relationship) significantly predicted the dependent variable (i.e. students satisfaction) $(\beta=0.18, p<0.05)$. The relationship between lecturer and students significantly predicted students' satisfaction after the other variables of courses, motivation, planning and lecturer's competency were controlled.

\section{Discussion}

It was found that there is a significant different of perceptions on teaching and learning quality for the constructs of subject of courses, lecturer's motivation, lesson planning and satisfaction based on gender. Whereas there is no significant difference based on gender for other constructs of instructional design, relationship between lecturer and students as well as lecturer's knowledge competency. Female students experienced higher satisfaction than male students. The result is similar with the findings by Hamidah et al . (2004) that lecturers did motivate and support their students but at a moderate level. Hence, lecturers need to be greatly motivated in implementing their teaching and learning activity, this is to encourage the students to be motivated too. Thus, it can be concluded that students, regardless of their gender perceived their lecturer's teaching quality solely based on the amount of knowledge, learning experience and satisfaction that they have gained from the lecturer. The difference of perceptions on teaching and learning quality, as satisfaction is not entirely related to gender bias.

Findings of this study confirm that improvement in teaching quality will relatively increase the level of satisfaction among students of the University of Riau, Indonesia. It can also be concluded that students perception on the lecturers' teaching quality definitely has certain impact on their satisfaction. This is also proven by a study conducted by Kusumandari (2006) who found that several significant factors which contributed to students' satisfaction were the learning process, the environment of the campus, services, facilities and security.

Generally, the findings show that gender does have signifcant impact on students' satisfactian. Lecturers' teaching quality is indeed the intermediatory factor between gender with students' satisfaction. The same finding was found by a study conducted by Prasetyaningrum (2009) who found that positive learning experience would positively influence students' satisfaction, and of course poor quality of lecturer's teaching would relatively result with low satisfaction. According to Kara (2004) who conducted a study in the College of Business Administration, Pennsylvania State University, found a positive and significant relationship between college students' experiences with their satisfaction (Ozgungor 2009). There is also a significant correlation between students' self-efficacy with students' assessment and self-confidence. Self-efficacy is closely related to good teaching and lecturers' ability to organize lessons with clear instructions. Satisfaction derives from the facilities, and appropriate services provided by the administration of the university to meet students' expectations. 
Satisfaction will be gained through the services and administration provided by the university as expected by students. Satisfaction is an achievement of personal experience through involvement in activities provided by the university. Results of the studies have proven that relationship between lecturer and students is a significant mediator for courses, motivation, instructional design and lecturers' competency, to effectively influence students' satisfaction. According to Elliott and Shin (2002) satisfaction is a good variable to be studied because it is beneficial for students and it is related to the courses offered, the improvement of motivation and it is also a winning force. In overall, it can be concluded that relationship between lecturer and students has positive contribution and significantly enhances students' satisfaction. Hence, it is important for lecturers to establish good relationship with their students in order to enhance students' satisfaction as students are the major clients of the university. Students always hope to establish good relationship wtih their lecturers, as the relationship would motivate the students to do better. Apart from that, lecturers need to be competent in handling their lessons for the purpose of achieving effective and meaningful teaching and learning experience.

\section{Implications}

University lecturers are professionals with huge responsibilities to continuosly improve the quality of their teaching and learning. Hence, they need to arm themselves with sophisticated and effective current teaching methods and strategies. Effective teaching does influence effective learning, and such, it is crucial for lecturers to know their students' perception on the lecturers and their teaching. Perception reactively influences the relationship between lecturer and his/her students in the class, which relatively contributes to their students' academic performance either negative or positively. An educator has to be efficient and competent particularly in handling his/her teaching and learning activities. It is important for educators to continuosly improve and develop their competencies particularly on teaching and to enrich themselves with the current knowledge, information and technologies. In the case of this study, it was found that students of the Riau University, perceived the level of lecturers competencies in teaching and learning is still at the moderate or average level.

Lecturers are the most important staff who responsible for the outcomes of students achievement through their instruction and guidance. Their professionalism and professional development are important factors to increase teaching effectiveness and to improve an institution. A lecturer is not simply a presenter or knowledge instructor, but a key role in a student's life as an advocate, mentor, motivator, moulder, facilitator, parent and lastly as an assessor. Therefore, it is important for lecturers to establish and improve a relationship with their students at least for the purpose of achieving the objectives of the roles. In addition, effective teaching requires a lecturer to diversify his/her elements of teaching and learning, such as applying various teaching methods, preparing teaching aids, in-depth understanding of the subject to be taught, understand students ability especially in receiving the lesson, to motivate students, to control students behaviours, to group students and to evaluate them. The quality of teaching refers to the ability of the presenter/lecturer to deliver contents or teaching skills that can be easily understood by students, in a memorable and fun way.

\section{Conclusion}

This study has successfully demonstrated that female students have higher perception on their satisfaction and their lecturers' teaching quality. The relationship between a lecturer and his/her students is an important factor which determines lecturers' quality in teaching and contributes to students' satisfaction. Apart from that, a lecturer needs to be competent, friendly, humorous, helpful, independent and efficient in performing his/her teaching duties. Thus, students' opinions, feedback and their needs should not be neglected but they are essential to enhance a better quality of teaching and learning. Due to that, great efforts should be taken as the top priority and taken seriously as one of the government's main agendas in improving the quality of teaching and learning.

\section{References}

Abdul Ghafar Mohammad (2003). Prinsip dan Amalan Pengajaran. Kuala Lumpur:Utusan Distributors Sdn Bhd. 91.

Baron, R. M., \& Kenny, D. A. (1986). The moderator-mediator variable distinction in social psychological research: Conceptual, strategic, and statistical considerations. Journal of Personality and Social Psychology, 51, 1173-1182.

Byrne, B. M. (2010). Structural equation modelling with AMOS: Basic concepts, applications and programming, (2nd Edition) Multivariate Applications Series, New York: Routledge.

Dutka, A. F. (1994). AMA handbook for customer satisfaction. Lincolnwood, E: NTC Business Books.

Elliott, K. M., \& Shin, D. (2002). Student satisfaction: an alternative approach to assessing this important concept. Journal of Higher Education Policy and Management,24(2),199-209.http://dx.doi.org/10.1080/1360080022000013518 
Groundwater-Smith, S. \& Mockler, N. (2003). Learning to Listen: Listening to Learn. Sydney: MLC School \& The Centre for Practitioner Research, University of Sydney (Forthcoming).

Guolla, M. (1999). Assessing the teaching quality to student satisfaction relationship: Applied customer satisfaction research in the classroom. Journal of Marketing Theory and Practice, Summer: 87-97.

Hamidah Abdul Rahman, Zainab Khalifah, Shoki Arif, Rosnah Sirin, Hafilah Zainal Abidin \& Norzarina Sulong (2004). Kajian mengenai tahap kualiti pendidikan tinggi dari perpektif pelajar di Universiti Teknologi Malaysia. Pusat Pengajian Penyelidikan. Universiti Teknolgi Malaysia.Monograph. Vol:75017

Hair F.J, Black W.C, Babin B.J, Anderson, R.E \& Tatham, R.L. (2006). Multivariate Data Analysis. 6th edition. United States: Prentice Hall

Hill, R., Stephens, D. and Smith, I. (2003), "Corporate social responsibility: an examination of individual firm behaviour", Business and Society Review, Vol. 108 No. 3, pp. 339-64

Kara, A. (2004). Business student satisfaction, intentions and retention in higher education: An empirical investigation. Pennsylvania State University-York Campus Oscar W. DeShields, Jr., California State University, Northridge.

Kamarul Azmi Jasmi. (2010). Guru Cemerlang Pendidikan Islam Sekolah enengah di Malaysia: Satu Kajian Kes.Tesis Dr. Falsafah, Universiti Kebangsaan Malaysia

Knight, P.T. (2002) Being a teacher in higher education. Buckingham: SRHE and Open University Press.

Kusumandari, R (2006). Faktor - faktor yang Mempengaruhi Kepuasan Mahasiswa Pascasarjana Universitas Muhammadiyah Surakarta. Tesis. Magister Manajemen Program Pascasarjana Universitas Muhammadiyah Surakarta

Marsh, H.W. and Hocevar, D. (1990). The Multidimensionality of Students' Evaluation of Teaching Effectiveness : The Generality of Factor Structures Across Academic Discipline, Instructor Level, and Course Level. www.mcmaster.ca/stlhl/documents/ student\%20Evaluation \%20of\%20 Teaching.pdf.

Mohammad, Ashori. (2007). Penelitian Tindakan Kelas, Bandung : CV Wacana Prima.

Nor Hidayu Shahadan (2006). Kualiti Pengajaran Pensyarah Kejuruteraan Yang Bukan Berlatarbelakangkan Pendidikan Ikhtisas Terhadap Pengalaman Pembelajaran Pelajar. Satu Tinjuan di KUiTTHO. KUiTTHO

Ozgungor., S. (2009). The relationships between students evaluations of teaching behaviours and self efficacy beliefs. Pamukkale Universiti. Department of Education, Educational Sciences. Denizili, 20020, Turkey, Procedia Social and Behavioral Sciences I (2009) 2687-2691.

Roediger, V., Thorsten, G. \& Isabelle, S. (2007). Service quality in higher education: The role of student expectations. Journal of Business Research, 60 (9), 949.

Umaedi. (1999). Manajemen Peningkatan Mutu Berbasis Sekolah : Sebuah pendekatan baru dalam pengelolaan sekolah untuk peningkatan Mutu. Internet Access: htpp : www perkembangan.net/directory.html. 